\title{
Subperiosteal abscess with epidural extension due to acute rhinosinusitis in a ten-year-old child
}

\author{
Abscesso subperiosteal com extensão epidural devido \\ à rinossinusite aguda em criança de dez anos
}

Epaminondas de Souza Mendes Junior ${ }^{1}$, Leandro Buzahr Nóbrega², Rafael Cerqueira Brandão², Danilo Augusto Rodrigues Teodoro 3 , Elielson Correia Dantas ${ }^{1}$, Érico Ramon Alves Batista ${ }^{4}$

\begin{abstract}
Acute rhinosinusitis is one of the most prevalent diseases of the upper airways. Anatomical factors present in children and young people allow for the onset of orbital complications. Although rare, intracranial complications of sinusitis account for a high degree of lethality, are more common in patients over the age of seven, and should be treated by a multidisciplinary team.

Keywords: Sinusitis/diagnosis; Epidural abscess/therapy; Abscess/diagnosis; Orbital cellulitis/complications; Orbit/surgery; Case reports
\end{abstract}

\section{ReSUMO}

A rinossinusite aguda é uma das afecções mais prevalentes das vias aéreas superiores. Fatores anatômicos presentes em crianças e jovens propiciam o aparecimento de complicações orbitárias. Embora mais raras, as complicações intracranianas das rinossinusites perfazem um grau alto de letalidade, são mais comuns em pacientes acima de sete anos, e devem ser tratadas por uma equipe multidisciplinar.

Descritores: Sinusite/diagnóstico; Abscesso epidural/terapia; Abscesso/diagnóstico; Celulite orbitária/complicações; Órbita/ cirurgia; Relatos de casos

\footnotetext{
${ }^{1}$ Deparament of Oculoplastics, Instituto Brasileiro de Oftalmologia para Prevenção da Cegueira, Salvador, BA, Brazil.

2 Residence Program in Ophthalmology, Instituto Brasileiro de Oftalmologia para Prevenção da Cegueira, Salvador, BA, Brazil.

${ }^{3}$ Deparament of Glaucoma, Instituto Brasileiro de Oftalmologia para Prevenção da Cegueira, Salvador, BA, Brazil.

${ }^{4}$ Deparament of Cataract, Instituto Brasileiro de Oftalmologia para Prevenção da Cegueira, Salvador, BA, Brazil.

Study conducted at: Instituto Brasileiro de Oftalmologia para Prevenção da Cegueira - IBOPC - Bahia. Presented at the XXXVII Brazilian Congress of Ophthalmology / XXX Pan-American Congress of Ophthalmology as a Case Report - Poster.
}

The authors declare no conflicts of interests.

Received for publication 10/01/2015 - Accepted for publication 01/03/2015 


\section{INTRODUCTION}

$\mathbf{R}$ hinosinusitis (RS) is characterized by the inflammation of the mucosa of the nose and paranasal sinuses, being one of the most prevalent diseases of upper airways and associated to several factors such as infections, allergies, mucosal disorders among others ${ }^{(1,2)}$.

Orbital complications are the most common ones in acute RS mainly due to anatomical factors ${ }^{(1-3)}$, and is more common among children and youngsters ${ }^{(1,2)}$. The urgency in the diagnosis and treatment is justified by the irreversible visual deficits, besides bone and neurological involvement with potential for significant morbidity and mortality ${ }^{(1,4)}$.

This report aims to present clinical profile, imaging and therapy of a case of subperiosteal abscess (ASP) with epidural extension in patient with acute rhinosinusitis, as well as the importance of the multidisciplinary approach.

\section{Case Report}

Patient aged 10 years old was admitted in an emergency unit in the city of Salvador - BA by the Department of Pediatrics complaining of edema in the left eye for 5 days in use of eyedrops (association of dexamethasone and ciprofloxacin hydrochloride). Pediatric examination showed the patient was afebrile with edema, redness and heat in upper left eyelid. The suspected diagnosis was orbital cellulitis, hospitalization was requested and the therapy started with the use of systemic antibiotic (oxacillin, ceftriaxone and metronidazole), corticosteroid (hydrocortisone) and analgesy (dipyrone). After two days without improvement, an ophthalmologist assessment was requested.

The patient's ophthalmological examination showed visual acuity in the right eye of 0.4 without correction, and impaired left eye due to important edema of the left upper eyelid associated to redness and local heat, being painful on palpation. The patient was also with accentuated chemosis preventing assessment of ocular motility and anterior segment of the left eye (Figure 1). Mapping of the retina of the right eye had no changes. The suspicion was SPA, and a CT scan of the skull and face was requested

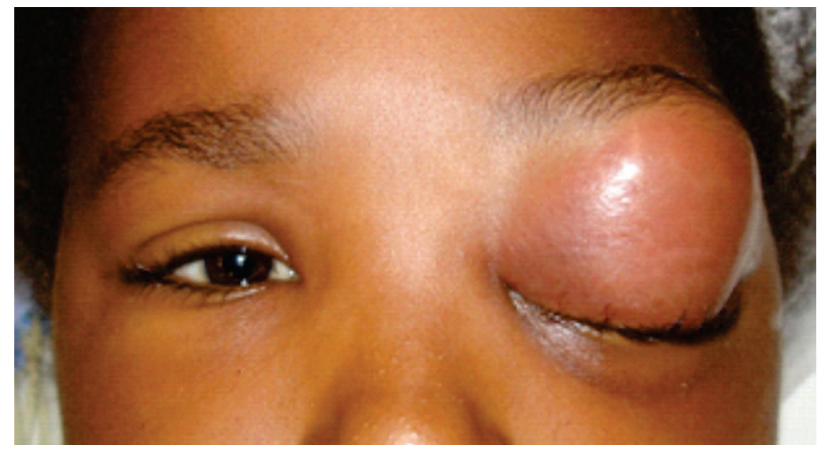

Figure 1: Left eye with severe edema in the upper eyelid associated to local redness and heat.

The CT scan showed an image suggestive of SPA with epidural extension and completion of frontal, ethmoid and maxillary sinuses (Figure 2).

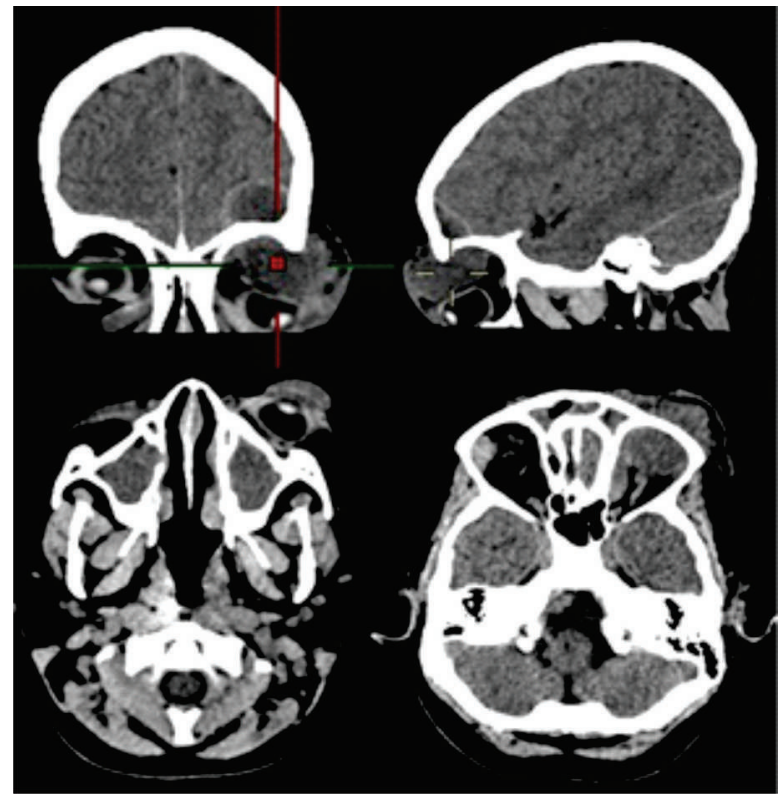

Figure 2: Image suggestive of SPA with epidural extension and completion of frontal, ethmoid and maxillary sinuses.

The choice was for surgical drainage along with neurosurgery. Surgical access was by left eyebrow incision. The patient was followed up in Salvador - BA in the otorhinolaryngology and ophthalmology services at Hospital Universitário Professor Edgard Santos (HUPES) and in the oculoplastics sector at Instituto Brasileiro de Prevenção à Cegueira (IBOPC) in the ambulatory, with treatment of the condition (Figure 3).

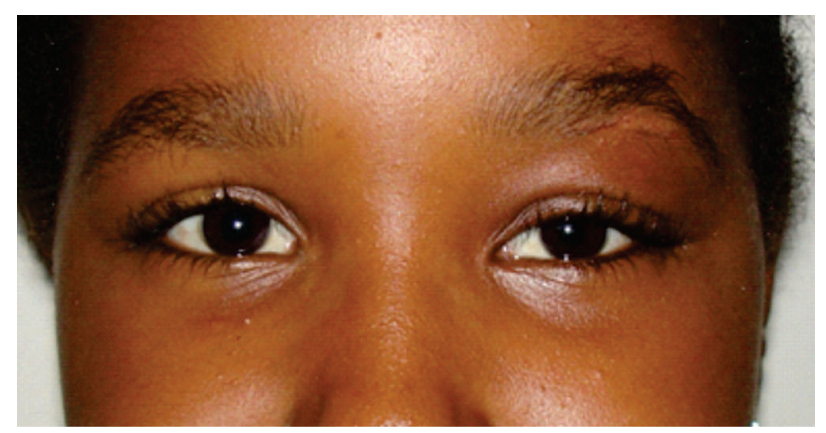

Figure 3: Treatment of the condition.

\section{Discussion}

Among all RS complications, the orbital ones are the most prevalent primarily due to anatomical factors affecting more the population of male youngsters. It is believed that this age group is the most affected by recurrent episodes of upper airway infection (UAI) and the presence of diploic bone with higher levels of vascularization in the sinuses ${ }^{(4)}$.

The case presented here shows involvement of a female 10-year-old patient.

Among the causes that explain the orbital complications in cases of RS is the anatomical component, such as the close relationship between orbital contents and ethmoidal labyrinth, the occurrence of congenital dehiscence on the orbital floor and 
papyraceous, as well as thrombophlebitis of ophthalmic veins facilitated by the absence of valves in that venous system, which allows free movement around the face, nasal cavity, paranasal sinuses, orbit and pterigoidal region. (3,-7) $^{(3)}$

It is known that the most widely used classification of secondary orbital infections to sinusitis is Chandler's, published in 1970, dividing the orbital cellulitis into the following categories: inflammatory edema; orbital cellulitis; subperiosteal abscess; orbital abscess and cavernous sinus thrombosis. However, after the advent of the computed tomography some authors have suggested a new classification of orbital complications secondary to sinusitis: orbital cellulitis; subperiosteal abscess and orbital abscess. ${ }^{(1,8,9)}$

According to the classification based on CT findings, orbital cellulitis is characterized by extra and intraconal infiltration without clear boundaries; subperiosteal abscess is defined by periorbital elevation of at least one bone wall adjacent paranasal sinus while the orbital abscess is represented by an heterogeneous density within the orbital fat (usually circular). ${ }^{(1,9)}$

Taking into account the proposed classification, the case reported here is an SPA with epidural extension due to RS. Subperiosteal abscesses of the orbit comprise a well known entity, and are capable of rapid progression and intracranial extension. ${ }^{(10,11)}$

The patient with SPA usually has eyelid edema, chemosis, non-axial proptosis, as well as inflammation of the conjunctiva, pain and restriction of ocular motility, which is consistent with the clinical findings of the patient reported. ${ }^{(3,4)}$

Although more rare, intracranial complications account for a high level of lethality, are more common in patients over seven years, and may be present silently in $15 \%$ of cases. It is presented by meningitis, epidural abscess, subdural empyema, thrombosis of venous sinuses and brain abscess. The simultaneous occurrence of infections may occur, and it increases the risk of death, so the treatment must be aggressive. . $^{(2,4,5,12)}$

Pediatricians, general practitioners, otorhinolaryngologists and neurosurgeons should be aware of the complications of RS, and should interact with each other due to the complications mentioned above. A complete and interactive team of medical service specialties, including the support of the radiology staff, would imply huge difference to the complicated cases of RS, since its fast progression and eventual early need for intervention because mortality can reach $5 \%$ of cases. ${ }^{(1,13)}$

The treatment of complicated RS consists of hospitalization, wide spectrum antibiotic therapy and multidisciplinary follow-up with ophthalmology, otorhinolaryngology and neurosurgery services, as explained above and effected in this case. It is known that surgical intervention is mandatory in patients with abscess, with no improvement after clinical treatment or those who have at least 1 of the following criteria: age greater than or equal to 9 years; frontal sinusitis; non-medial SPA; severe SPA; suspicion of subperiosteal infection by anaerobic; SPA recurrence after previous drainage; evidence of chronic sinusitis; acute damage to the optic nerve or retina; infection of dental origin..$^{(4,13)}$

In conclusion, RS can cause severe complications, most often in the orbits due to the close relation between them and the paranasal sinuses. The orbital and intracranial simultaneous involvement is extremely rare, and due to the increased mortality rate in these cases a multidisciplinary approach should be as early and organized as possible.

\section{ReFERENCES}

1. Velasco e Cruz AA, Demarco RC, Valera FCP, Santos AC, Anselmo-Lima WT, Marquezini RMS. Complicações orbitárias da rinossinusite aguda: uma nova classificação. Rev Bras Otorrinolaringol 2007;73(5):684-8.

2. Mekhitarian Neto L, Pignatari S, Mitsuda S, Fava AS, Stamm A. Sinusite aguda em crianças: estudo retrospectivo de complicações orbitárias. Rev Bras de Otorrinolaringol 2007;73(1):81-5.

3. Diretrizes Brasileiras de Rinossinusites. Rev Bras Otorrinolaringol 2008;74(2):6-59.

4. Souza LA, Verde RCL, Lessa BF, Lima CMF, Lessa MM, Lessa HA. Complicação Orbital e Intracraniana Devido à Rinossinusite Aguda: Relato de Caso. Arq Int Otorrinolaringol 2011;15(2):241-4.

5. Herrmann BW, Forsen Jr JW. Simultaneous intracranial and orbital complications of acute rhinosinusitis in children. Int J Pediatr Otorhinolaryngol. 2004; 68(5):619-25.

6. Reid JR. Complications of pediatric paranasal sinusitis. Pediatr Radiol. 2004; 34(12):933-42.

7. Howe L, Jones NS. Guidelines for the management of periorbital cellulitis/abscess. Clin Otolaryngol Allied Sci. 2004; 29(6):725-8.

8. Chandler JC, Lagenbrunner DL, Stevens ER. The pathogenesis of orbital complications in acute sinusitis. Laryngoscope 1970;80:1414-18.

9. Pereira FJ, Velasco e Cruz AA, Anselmo-Lima WT, Elias Júnior J. Computed tomographic patterns of orbital cellulitis due to sinusitis. Arq. Bras. Oftalmol. 2006; 69(4):513-8.

10. Moloney JR, Badham NJ, McRae A. The acute orbit. Preseptal (periorbital) cellulitis, subperiosteal abscess and orbital cellulitis due to sinusitis. J Laryngol Otol Suppl 1987;12:1-18.

11. Rubinstein JR, Handler SD. Orbital and periorbital cellulitis in children. Head Neck Surg 1982;5:15-21.

12. Jones NS, Walker JL, Bassi S, Jones T, Punt J. The intracranial complications of rhinosinusitis: can they be prevented ?. Laryngoscope. 2002; 112(1):59-63. Garcia GH, Harris GJ. Criteria for nonsurgical management of subperiosteal abscess of the orbit. Oph

\section{Corresponding author:}

Epaminondas de Souza Mendes Junior

R. Pedro Lessa, 118, Canela, Salvador - BA. ZIP Code: 40110-050

Fax: (71) 3173-8218

E-mail: epamjr@ig.com.br 